\title{
一种大环类双核非离子型磁共振对比剂的合成及弛豫性能
}

\author{
周 进 $\dagger, a, b$ \\ 孙宏顺 $\dagger, *, a, b$ \\ 李玉龙 $b$ \\ 蒋 葓 $b$ \\ 郭成*,a沈临江 $c$ \\ ( ${ }^{a}$ 南京工业大学化学与分子工程学院 南京 211816) \\ ( $b$ 南京科技职业学院 江苏省磁共振靶向显像剂工程实验室 南京 210048) \\ ( ${ }^{c}$ 南京工业大学数理科学学院 南京 211816)
}

\begin{abstract}
摘要 磁共振成像技术被广泛应用于诊断医学和软组织成像, 而磁共振对比剂有助于提高成像对比度. 报道了一种基 于钝-DOTA-酰肼结构 $(\mathrm{DOTA}=1,4,7,10$-四氮杂环十二烷-1,4,7,10-四乙酸)的新型双核非离子型磁共振对比剂 $(\mathrm{Gd}-\mathrm{DOTAH})_{2} \mathrm{SBDC}$ 的设计、合成及弛豫性能. 在 $0.5 \mathrm{~T}$ 磁场下，测得其纵向弛豫率为每分子 $10.6 \mathrm{~L} \cdot \mathrm{mmol}^{-1} \cdot \mathrm{s}^{-1}$ 或 5.3 $\mathrm{L} \cdot \mathrm{mmol}^{-1} \cdot \mathrm{Gd}^{-1} \cdot \mathrm{s}^{-1}$, 高于目前临床使用的单核大环对比剂钝- DOTA. 体外磁共振成像研究显示该磁共振对比剂具有提 高诊断灵敏度和准确度的特点. 同时，该对比剂分子中含有能与髓鞘特异性结合的二苯乙烯结构，具有成为髓鞘靶向 磁共振对比剂的应用潜力. 另外，探讨了该对比剂的两条合成路线(A 和 B)，总收率分别为 $70 \%$ 和 $75 \%$. 综合考虑适用 性，合成路线 B 更优.
\end{abstract}

关键词＼cjkstart磁共振成像; 对比剂; 合成; 弛豫率; DOTA-酰肼; 钝-DOTA; 髓鞘

\section{Synthesis and Relaxivity of One Macrocyclic Binuclear Nonionic Magnetic Resonance Contrast Agent}

\author{
Zhou, $\operatorname{Jin}^{\dagger, a, b} \quad$ Sun, Hongshun ${ }^{\dagger, *, a, b}$ \\ Li, Yulong ${ }^{b}$ \\ Jiang, Hong ${ }^{b}$ \\ Guo, Cheng*,a \\ Shen, Linjiang ${ }^{c}$ \\ ( ${ }^{a}$ College of Chemistry and Molecular Engineering, Nanjing Tech University, Nanjing 211816)
}

( ${ }^{b}$ Targeted MRI Contrast Agents Laboratory of Jiangsu Province, Nanjing Polytechnic Institute, Nanjing 210048)

( ${ }^{c}$ School of Physical and Mathematical Sciences, Nanjing Tech University, Nanjing 211816)

\begin{abstract}
Magnetic resonance imaging (MRI) is widely employed in diagnostic medicine and soft tissue imaging. Contrast agents (CAs) can improve the specificity of enhanced MRI images. Herein, the design, synthesis and relaxivity of a novel binuclear nonionic Gd-based DOTA-hydrazide (DOTA = 1,4,7,10-tetraazacyclododecan-1,4,7,10-tetraacetic acid) derived MRI contrast agents, $(\mathrm{Gd}-\mathrm{DOTAH})_{2}$-SBDC, were reported. The improved longitudinal relaxivity was determined as $10.6 \mathrm{~L}^{-\mathrm{mmol}}$ $1 \cdot \mathrm{s}^{-1}$ per molecule or $5.3 \mathrm{~L} \cdot \mathrm{mmol}^{-1} \cdot \mathrm{Gd}^{-1} \cdot \mathrm{s}^{-1}$ at $0.5 \mathrm{~T}$, which is higher than that of the mononuclear clinical macrocyclic agent Gd-DOTA. In vitro MRI studies confirmed its suitability for use as a MRI contrast agent with improved diagnostic sensitivity and accuracy. Furthermore, the stilbene moiety endows it with myelin-targeting capabilities. In addition, two synthetic routes (A and $\mathrm{B}$ ) for this contrast agent were compared, providing overall yields of $70 \%$ and $75 \%$, respectivily, and route $\mathrm{B}$ was deemed superior.
\end{abstract}

Keywords magnetic resonance imaging; contrast agents; synthesis; relaxivity; DOTA-hydrazide; Gd-DOTA; myelin

\footnotetext{
* Corresponding authors. E-mail: njutshs@126.com; guocheng@njtech.edu.cn

Received February 5, 2021; revised March 12, 2021; published online April 9, 2021.

Project supported by the Natural Science Foundation of Jiangsu Province (No. BK20181486), the Natural Science Foundation of the Jiangsu Higher Education Institutions (No. 17KJB320001), the Overseas Training Program for Excellent Young Teachers and Principals of Jiangsu Province and the Qing Lan Project of Jiangsu Province.

江苏省自然科学基金(No. BK20181486)、江苏省高校自然科学基金(No. 17KJB320001)、江苏省高校优秀中青年教师和校长境外研修计划和江苏省青 蓝工程资助项目。

†共同第一作者(These authors contributed equally to this work).
} 


\section{Introduction}

Magnetic resonance imaging (MRI) has become one of the most commonly implemented diagnostic techniques as it is nonionizing, noninvasive, and deep penetrating, and it provides high spatial resolution for whole-body diagnosis. ${ }^{[1-2]}$ To improve specificity and acquire high-intensity MR signals, contrast agents (CAs) are widely used to facilitate the acquisition and interpretation of MRI images. Clinical-used CAs are generally coordination complexes in which a $\mathrm{Gd}^{\mathrm{III}}$ ion is encapsulated within octadentate chelators derived from polyaminocarboxylate anions, such as DTPA (diethylenetriaminepentaacetic acid) and DOTA (1,4,7,10-tetraazacyclododecan-1,4,7,10-tetraacetic acid). According to a recent report, Gd-based CAs (GBCAs) are employed in approximately $40 \%$ of all MRI exams and $60 \%$ of neuro-MRI exams. ${ }^{[3]}$ However, the release of $\mathrm{Gd}^{3+}$ ions from GBCAs causes nephrogenic systemic fibrosis (NSF) in patients with impaired renal clearance and gadolinium accumulation in the brains. ${ }^{[4-7]}$ In recent years, considerable efforts have been directed toward the development of tissue specific MRI CAs with higher proton relaxivities, as this allows for the use of lower doses.

According to the Solomon-Bloembergen-Morgan (SBM) equation, the relaxivity of GBCAs is primarily determined by residence time $\left(\tau_{\mathrm{M}}\right)$, the number of first-shell (inner) water molecules $(q)$, rotational correlation time $\left(\tau_{\mathrm{R}}\right)$, and electron spin relaxation time $\left(T_{1 \mathrm{e}}\right)$. For small molecular weight GBCAs, enhancing the relaxivity can be achieved by either increasing $q$ or prolonging $\tau_{\mathrm{R}} \cdot{ }^{[8-10]}$ As an increase in $q$ is often accompanied by a decrease in thermodynamic and kinetic stability, prolonging $\tau_{\mathrm{R}}$ is generally practiced. One of the most efficient approaches for achieving this is by constructing multiple-nuclear agents by fusing several small-molecule agents. ${ }^{[11-13]}$

Myelin is the axon-protecting sheath surrounding the nerves of vertebrates, and it facilitates impulse conduction. Damage to myelin or demyelination is associated with various neurodegenerative diseases such as multiple sclerosis (MS). ${ }^{[14]}$ Over the past decades, MRI has played an important role in the diagnosis and disease management of MS. However, due to the lack of myelin-specific MRI CAs, demyelination and inflammation can not be differentiated by conventional MRI. To address this problem, efforts have been devoted to improving the MR specificity of myelin imaging. Luca et al. ${ }^{[15-16]}$ designed and synthesized two types of myelin-specific MRIs, namely CAs Gd-DODAS (Chart 1, A) and MIC (Chart 1, B), based on a stilbene binding moiety and demonstrated their efficacy in binding specifically to myelin in vitro and in vivo.

Over the past decade, our group has been extensively exploring magnetic resonance imaging and near infrared imaging. We have designed and synthesized two nonionic binuclear MRI CAs, (Gd-DOTAH) $)_{2}$ DYMB (Chart 1, C) and (Gd-DOTAH) $)_{2}$ DYMBP (Chart 1, D), using diyli-

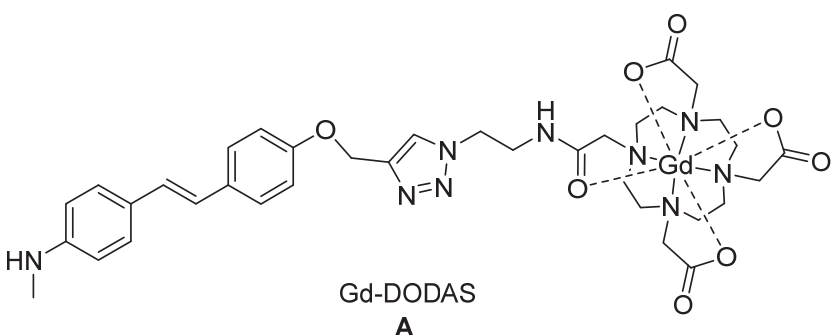

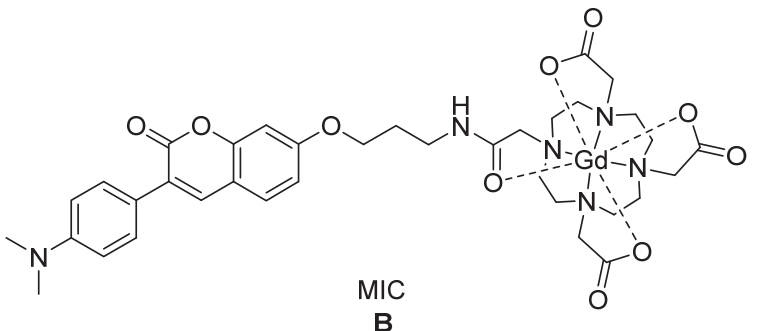

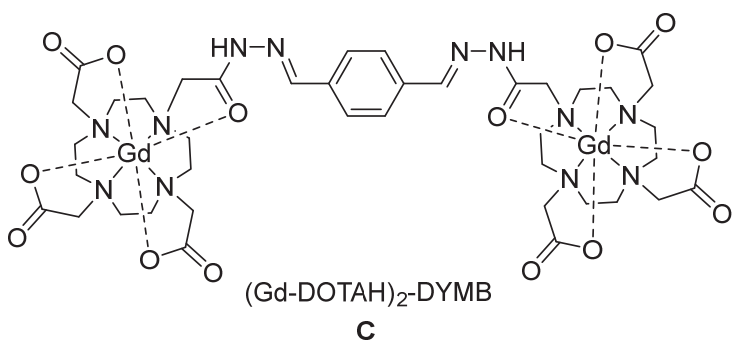

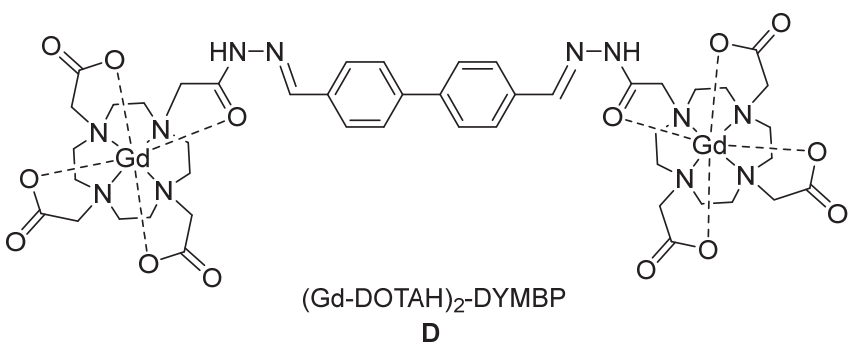

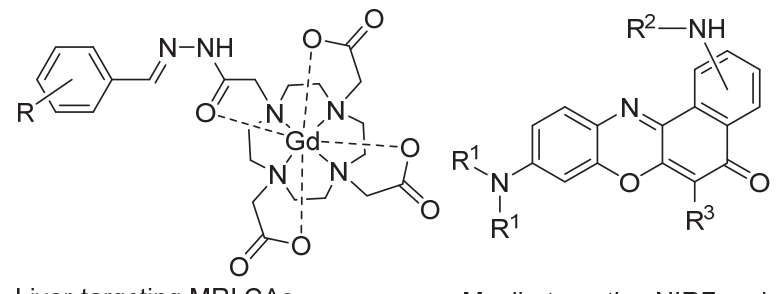

Liver-targeting MRI CAs E
Myelin-targeting NIRF probes $\mathrm{F}$

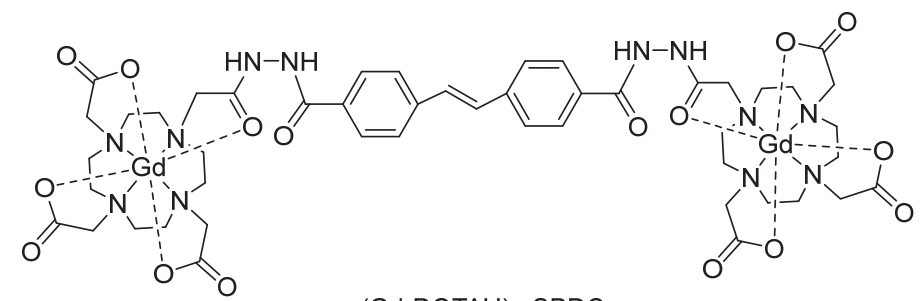

$(\text { Gd-DOTAH })_{2}$-SBDC

G

Chart 1 Structures of some compounds concerned 
denemethylbenzene and diylidenemethylbiphenyl, respectively, as the linkers. The longitudinal relaxivities of the two CAs were 11.4 and $11.7 \mathrm{~L} \cdot \mathrm{mmol}^{-1} \cdot \mathrm{s}^{-1}$ per molecule at 0.5 $\mathrm{T}$, respectively. ${ }^{[17]}$ In addition, we have reported a series of Gd-based DOTA-hydrazide (DOTAH) derived MRI contrast agents (Chart 1, E), some of which exhibited margin ally higher $r_{1}$ relaxivities and ideal contrast enhancements in $T_{1}$-weighted MR images compared with the clinical contrast agent Gd-DOTA and could be used as liver-targeting MRICAs. These types of binuclear structures can ameliorate the occurrence of NSF resulting from the use of linear agents. ${ }^{[18]}$ For myelin imaging, we designed and synthesized a series of Nile Red Analogs (Chart 1, F), bearing structural features resembling stilbene. In vitro, ex vivo and in vivo experiments indicated that they were capable of crossing the blood-brain barrier (BBB) and binding specially to myelin tracts, and were therefore suitable for use as near-infrared fluorescence (NIRF) probes for myelin-targeted imaging. ${ }^{[19]}$

Herein, we report a novel dimeric nonionic MRI CAs, (Gd-DOTAH) 2 -SBDC (SBDC: 4,4'-stilbenedicarboxylic, Chart $1, \mathbf{G})$, in which the two DOTAH units that function as $\mathrm{Gd}^{3^{+}}$chelators are affixed to a stilbenedicarbonyl moiety, to investigate its potential application as a myelin-targeting MRI CA. Relaxometric studies and $T_{1}$-weighted MR imaging were performed for this complex.

\section{Results and discussion}

\subsection{Design and synthesis}

To improve the specificity of enhanced MR images for MS diagnosis, we aimed to develop a myelin-targeting MRI $\mathrm{CA}$ with a high relaxivity. The structure-activity relationship (SAR) studies of a library of compounds suggested that the stilbene framework is crucial for binding to myelin. ${ }^{[20-24]}$ On the other hand, we decided to construct binuclear CAs to attain a high relaxivity. Accordingly, 4,4'-stilbenedicarboxylic acid was chosen as the starting material for the construction of binuclear MRI CAs that could potentially be utilized for myelin targeting. DOTAH was selected as the $\mathrm{Gd}^{3^{+}}$chelator, because this macrocyclic ligand exhibits superior thermodynamic stability and slower dissociation kinetics, which are beneficial for preventing transmetallation in vivo, compared to linear ligands, such as DTPA. In addition, $\mathrm{Gd}^{3+}$ binding neutralizes the charges of three acetic groups of DOTAH, resulting in nonionic CAs, beneficial for lowering osmotic pressure. Moreover, complex $(\mathrm{Gd}-\mathrm{DOTAH})_{2}$-SBDC is more stable than $(\mathrm{Gd}-\mathrm{DOTAH})_{2}-$ DYMB and (Gd-DOTAH) $)_{2}$-DYMBP due to the susceptibility of the $\mathrm{C}=\mathrm{N}$ bonds of (Gd-DOTAH $)_{2}-\mathrm{DYMB}$ and (Gd-DOTAH $)_{2}$-DYMBP toward hydrolysis under acidic conditions. ${ }^{[27]}$

The synthetic procedure for complex (Gd-DOTAH $)_{2}$ SBDC is outlined in Scheme 1. Two different routes (A and

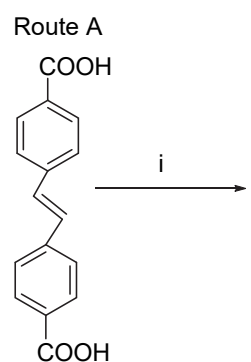

1<smiles>O=C(Cl)c1ccc(C=C2CCCCC2C(Cl)(Cl)Cl)cc1</smiles>

2

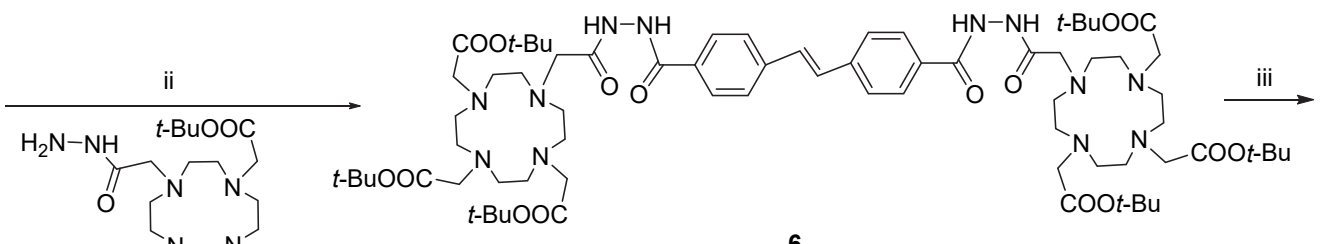

6 (t-Bu-DOTAH) $)_{2}$-SBDC

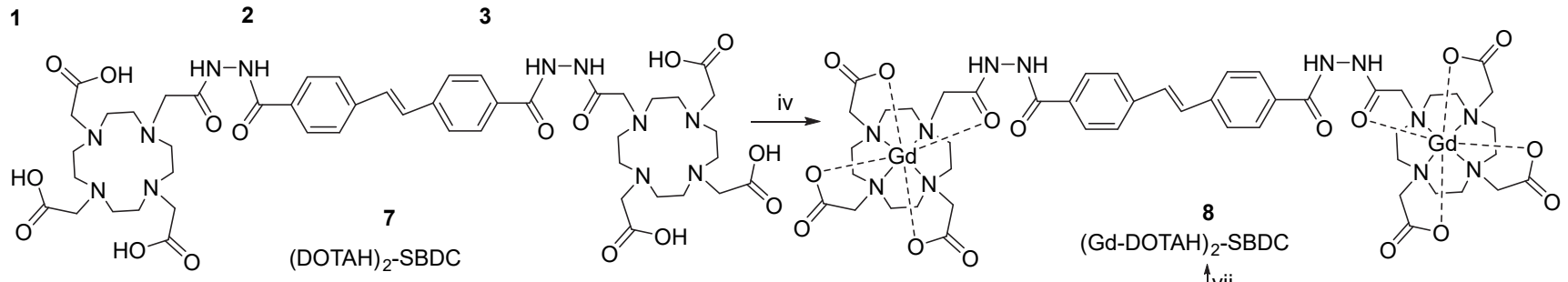

Route B
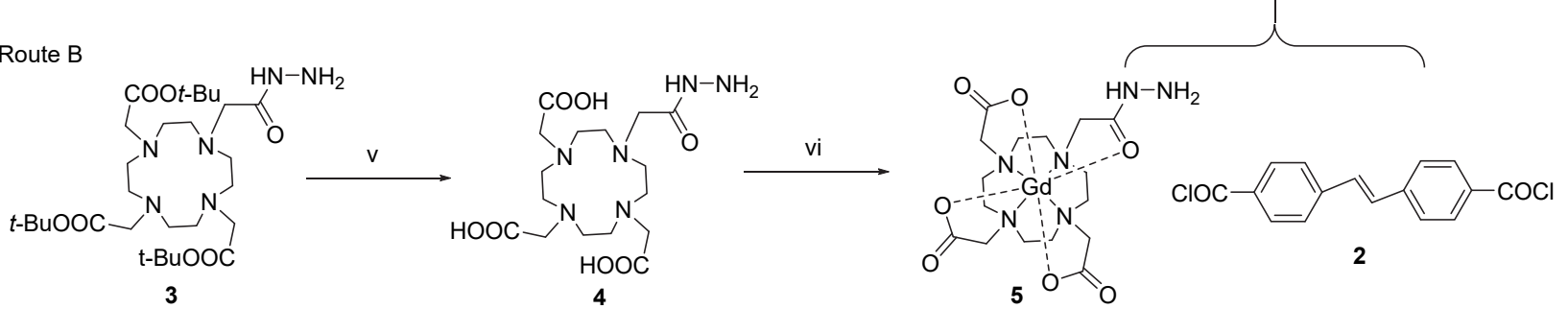

Reagents and conditions: (i) $\mathrm{SOCl}_{2}$, DMF; (ii) $\mathrm{CH}_{2} \mathrm{Cl}_{2}, \mathrm{~K}_{2} \mathrm{CO}_{3}$; (iii) TFA, r.t, $24 \mathrm{~h}$; (iv) $\mathrm{GdCl}_{3}, 50{ }^{\circ} \mathrm{C}, 24$ h; (v) TFA, r.t, 24 h; (vi) $\mathrm{GdCl}{ }_{3}, 50{ }^{\circ} \mathrm{C}, 24$ h; (vii) DMF, $\mathrm{K}_{2} \mathrm{CO}_{3}$

Scheme 1 Synthetic routes (A and B) for complex 8 
B) for its synthesis are considered. In route A, the first step entailed the formation of an acid chloride from 4,4'-stibenedicarboxylic acid and $\mathrm{SOCl}_{2}$, affording 4,4'-stibenedicarbonyl chloride (2), which was used directly in the next step without purification. $t$-Bu-DOTAH (3) was synthesized from cyclen according to our previously published proto$\mathrm{col}^{[25]}$ Intermediate $\left(t\right.$-Bu-DOTAH) ${ }_{2}$-SBDC (6) was obtained from the coupling of $\mathbf{2}$ and $\mathbf{3}$ in $90 \%$ yield. Then, $\mathbf{6}$ was deprotected using trifluoroacetic acid (TFA) to deliver (DOTAH) ${ }_{2}$-SBDC (7). The target complex (Gd-DOTAH) $)_{2}$ SBDC (8) was obtained by combining 7 and $\mathrm{GdCl}_{3}$ in aqueous media at $50{ }^{\circ} \mathrm{C}$. The overall yield of route $\mathrm{A}$ was $70 \%$. In route $\mathrm{B}$, the DOTAH gadolinium complex GdDOTAH was first synthesized, which could then be used for the synthesis of various gadolinium-based contrast agents in one step. Gd-DOTAH (5) was obtained by combining $\mathrm{GdCl}_{3}$ and DOTAH (4), which was generated from the TFA-catalyzed ester hydrolysis of $t$-Bu-DOTAH (3). Finally, the Gd complex precursor 5 was reacted with 4,4'-stibenedicarbonyl chloride (2) to afford the target product (Gd-DOTAH) 2 -SBDC (8). Complex 8 was purified on a C-18 SPE column. The overall yield of route B was $75 \%$. Thus, route $\mathrm{B}$ was higher yielding than route $\mathrm{A}$. Moreover, the use of Gd-DOTAH (5) as an intermediate is more convenient for the facile preparation of various gadolinium-based contrast agents. Therefore, synthetic route B was deemed more suitable for the preparation of GdDOTAH-based MRI contrast agents in this study.

\subsection{In vitro $\mathrm{MRI}$}

To evaluate the level of contrast enhancement of the
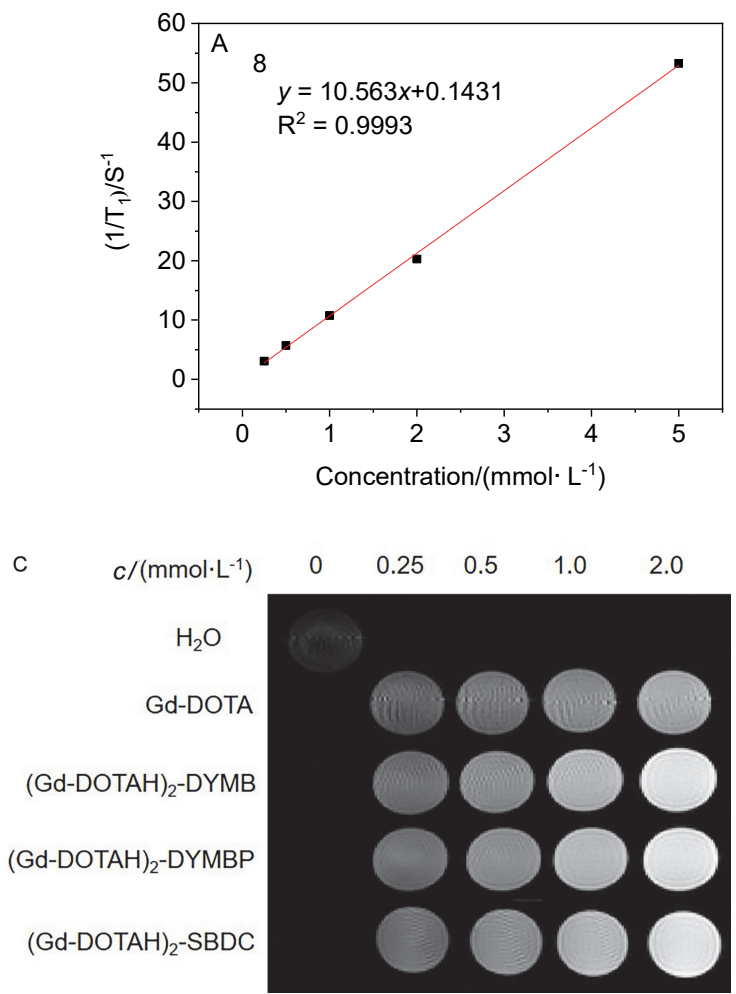

developed agent, longitudinal relaxivity $r_{1}$ and transverse relaxivity $r_{2}$ were calculated from the linear fitting of $1 / T_{1}$ and $1 / T_{2}$ as a function of complex concentrations (Figure 1, A, B ${ }^{[28-29]}$. Commercially available Gd-DOTA, self-prepared (Gd-DOTAH) $)_{2}$-DYMB, and (Gd-DOTAH) $)_{2}$-DYM $\mathrm{BP}$ were used for comparison. The longitudinal relaxivity $\left(r_{1}\right)$ of $(\mathrm{Gd}-\mathrm{DOTAH})_{2}-\mathrm{SBDC}\left(M_{\mathrm{r}}=1377\right)$ was $10.6 \mathrm{~L} \cdot$ $\mathrm{mmol}^{-1} \cdot \mathrm{s}^{-1}$ per molecule or $5.3 \mathrm{~L} \cdot \mathrm{mmol}^{-1} \cdot \mathrm{s}^{-1}$ per Gd at 0.5 $\mathrm{T}$ (Table 1), which is higher than that of the current clinical mononuclear macrocyclic CA, Gd-DOTA $\left(3.6{\mathrm{~L} \cdot \mathrm{mmol}^{-}}^{-1}\right.$ $\left.\mathrm{s}^{-1}, M_{\mathrm{r}}=563\right)$. The improvement in relaxivity was principally attributed to the increase in molecular weight and the curbed rotational correlation time $\left(\tau_{\mathrm{R}}\right)$ resulting from increased molecular rigidity. However, the relaxivity was lower than that of our previously reported (Gd-DOTAH $)_{2}$ DYMB $\left(11.4 \mathrm{~L} \cdot \mathrm{mmol}^{-1} \cdot \mathrm{s}^{-1}, M_{\mathrm{r}}=1244\right)$ and $(\mathrm{Gd}-$

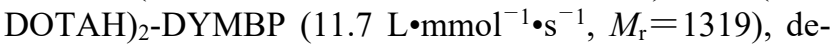
spite its molecular weight being the highest among them (Table 1). Presumably the presence of the vinyl group in the molecule allows for a higher degree of molecular rotation, which affects its relaxation performance. The $r_{2} / r_{1}$ ratio was calculated as 1.16 (Table 1); the low $r_{2} / r_{1}$ value indicates that the complex can be used as a $T_{1}$-weighted MRI CA. As shown in Figure $1 \mathbf{C}$ and $\mathbf{D}, 8$ presents excellent positive $T_{1}$ contrast enhancement akin to (Gd-DOTAH $)_{2}-\mathrm{DYMB}$ and (Gd-DOTAH) $)_{2}$-DYMBP, and the bright- ness of the MR images increased with the increasing concentrations, showing a clear dose-dependent color change, because the relaxation of the proton increases with increasing concentration. Moreover, as a potential myelin- targeting binuclear
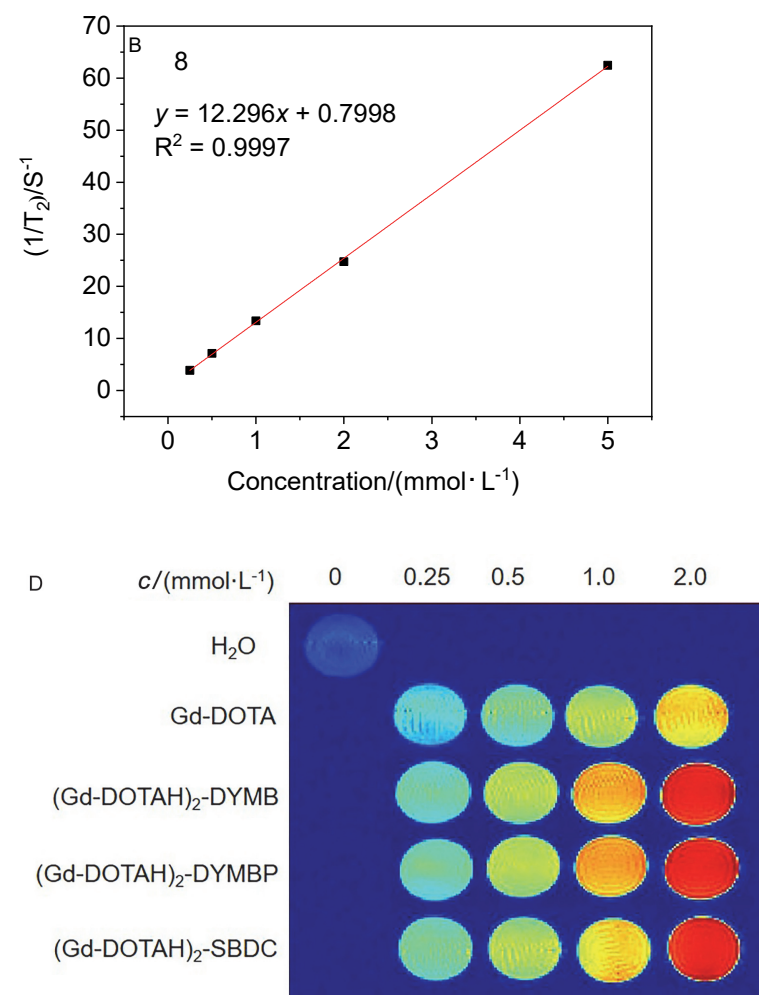

Figure 1 MR relaxivities and $T_{1}$-weighted $\mathrm{MR}$ images at $0.5 \mathrm{~T}$

$r_{1}$ and $r_{2}$ relaxivity curves of $\mathbf{8}(\mathrm{A}, \mathrm{B})$; $\mathrm{T}_{1}$-weighted MR images at varying concentrations in the range of 0.25 to $2.0 \mathrm{mmol} / \mathrm{L}(\mathrm{C}, \mathrm{D})$. 
Table 1 The $r_{1}$ and $r_{2}$ values and the ratios of $r_{2} / r_{1}$ of the synthesized complex at $0.5 \mathrm{~T}^{a}$

\begin{tabular}{clcccc}
\hline Entry & \multicolumn{1}{c}{ Gd-complexes } & $r_{2} /\left(\mathrm{L}^{\prime} \cdot \mathrm{mmol}^{-1} \cdot \mathrm{s}^{-1}\right)$ & $r_{1} /\left(\mathrm{L}^{\prime} \cdot \mathrm{mmol}^{-1} \cdot \mathrm{s}^{-1}\right)$ & $r_{2} / r_{1}$ & Ref. \\
\hline 1 & (Gd-DOTAH) 2 -SBDC & 12.3 & 10.6 & 1.16 & This work \\
2 & Gd-DOTA & 4.3 & 3.6 & 1.19 & {$[26]$} \\
3 & (Gd-DOTAH) 2 -DYMB & 13.2 & 11.4 & 1.16 & {$[17]$} \\
4 & (Gd-DOTAH) 2 -DYMBP & 14.0 & 11.7 & 1.20 & {$[17]$} \\
\hline
\end{tabular}

${ }^{a}$ Gd-DOTA, $(\mathrm{Gd}-\mathrm{DOTAH})_{2}$-DYMB and (Gd-DOTAH) ${ }_{2}$-DYMBP were as compares.

MR probe, (Gd-DOTAH) $)_{2}$ SBDC exhibited a higher relaxivity compared to that of reported MIC and Gd-DODAS $\left(5.8 \mathrm{~L} \cdot \mathrm{mmol}^{-1} \cdot \mathrm{s}^{-1}\right.$ at $0.5 \mathrm{~T}$ for both $\left.{ }^{[15-16]}\right)$. Hence, the developed binuclear macrocyclic contrast agent can be used at lower dosages and consequently provide reduced clinical toxicity.

\section{Conclusions}

In summary, a nonionic binuclear MRI CAs, (Gd-DOT$\mathrm{AH})_{2}$-SBDC was designed and synthesized via two different synthetic routes (A and B). Route B was found to be more suitable for the preparation of Gd-DOTAH-based MRI contrast agents as it provided a higher yield and a more useful intermediate. Meanwhile, stilbenedicarbonyl was selected as the linker for (Gd-DOTAH) $)_{2}$-SBDC, because the stilbene motif is crucial for myelin binding. Thus, the developed complex has considerable potential for use as a myelin-targeting MRI CA. In addition, the feasibility of utilizing it as a $T_{1}$-weighted MRI CA was explored. The prepared agent provided a good positive imaging effect and a low $r_{2} / r_{1}$ ratio, confirming its suitability for use as a $T_{1}$-weighted MRI CA. The longitudinal relaxivity was found to be $10.6 \mathrm{~L}^{\prime} \mathrm{mmol}^{-1} \cdot \mathrm{s}^{-1}$ per molecule or $5.3 \mathrm{~L} \cdot$ $\mathrm{mmol}^{-1} \cdot \mathrm{Gd}^{-1} \cdot \mathrm{s}^{-1}$ at $0.5 \mathrm{~T}$, which is higher than that of the FDA approved mononuclear macrocyclic agent Gd-DOTA and the reported myelin-targeting probes MIC and Gd-DODAS. Therefore, the developed contrast agent can be used at lower dosages, allowing for reduced clinical toxicity. Moreover, complex (Gd-DOTAH) $)_{2}$-SBDC is more stable than our previously reported (Gd-DOTAH) $)_{2}$-DYMB and $(\mathrm{Gd}-\mathrm{DOTAH})_{2}$-DYMBP, as the $\mathrm{C}=\mathrm{N}$ bonds of the two latter complexes are susceptible to hydrolysis under acidic conditions. Animal experiments related to myelin imaging are on the way.

\section{Experimental section}

\subsection{General procedures}

All chemicals and reagents were used as received without further purification. Unless specially mentioned, all the reactions were performed open to air. Reactions were monitored by thin-layer chromatography (TLC) and visualized by a dual short/long wavelength UV lamp. Flash column chromatography was performed using $200 \sim 400$ mesh silica gel (Fisher). NMR spectra were recorded on a Bruker AVANCE AV-300 NMR spectrometer at room temperature. Spectra were referenced tointernal standards (TMS in $\mathrm{CDCl}_{3}$ and TMSP in $\mathrm{D}_{2} \mathrm{O}$ ). Multiplicity and coupling constants $(J)$ were calculated automatically on Mes-
tReNova 10.0, a NMR processing software from Mestrelab Research. MS (ESI) was determined by using a microTOF-Q II HRMS/MS instrument (Bruker). Element analysis was determined by using a Perkin-Elmer 240c elemental analysis instrument. In vitro MRI testing and $T_{1}$ relaxation time measurements were tested at a 0.5 T NMR120-Analyst NMR Analyzing and Imaging system (Niuman Corporation, Shanghai, China). Melting points were determined in open capillaries and were uncorrected.

\subsection{Synthesis}

\subsubsection{Synthesis of DOTAH (4)}

A solution of $3(1.17 \mathrm{~g}, 2 \mathrm{mmol})$ in TFA $(15 \mathrm{~mL})$ was stirred at room temperature for $24 \mathrm{~h}$. TFA was removed under reduced pressure and the residue was dissolved in ethyl acetate $(5 \mathrm{~mL})$. Freezing for $12 \mathrm{~h}$, filtered to give compound $4^{[27]}$ as a white solid (quantitative). m.p. 182.6 $183.8{ }^{\circ} \mathrm{C} ;{ }^{1} \mathrm{H}$ NMR $\left(300 \mathrm{MHz}, \mathrm{D}_{2} \mathrm{O}\right) \delta: 4.03 \sim 2.93(\mathrm{~m}$, $24 \mathrm{H}) ;{ }^{13} \mathrm{C}$ NMR $\left(126 \mathrm{MHz}, \mathrm{D}_{2} \mathrm{O}\right) \delta: 174.5,170.5,56.3$, 53.1, 52.5, 51.6, 51.0, 48.7, 48.2. HRMS calcd for $\mathrm{C}_{16} \mathrm{H}_{30} \mathrm{~N}_{6} \mathrm{O}_{7}[\mathrm{M}+\mathrm{H}]^{+}$419.2249, found 419.2251.

\subsubsection{Synthesis of Gd-DOTAH (5)}

To a solution of $4(0.83 \mathrm{~g}, 2 \mathrm{mmol})$ in water $(20 \mathrm{~mL})$ was added a solution of $\mathrm{GdCl}_{3}$ in water $(0.05 \mathrm{~mol} / \mathrm{L}, 40 \mathrm{~mL}, 2$ $\mathrm{mmol}$ ) while maintaining the $\mathrm{pH}$ at 6.5 by addition of 1 $\mathrm{mol} / \mathrm{L} \mathrm{NaOH}$. The solution was stirred at $50{ }^{\circ} \mathrm{C}$ for $24 \mathrm{~h}$. The solution was loaded on a Hypersep C-18 cartridge, and the stationary phase was washed extensively with water. The product was recovered after gradient elution with $\mathrm{MeOH} / \mathrm{H}_{2} \mathrm{O}(V: V=1: 9$ to $3: 2)$. The fractions containing the product were evaporated under reduced pressure to give $\mathbf{5}^{[27]}(1.01 \mathrm{~g}$, yield $88 \%)$ as a white solid. m.p.> $300{ }^{\circ} \mathrm{C}$; ESI-MS m/z: $596.1[\mathrm{M}+\mathrm{Na}]^{+}$. A correct Gd isotope pattern was observed. Anal. calcd for $\mathrm{C}_{16} \mathrm{H}_{27} \mathrm{GdN}_{6} \mathrm{O}_{7}$ : C 33.56, H 4.75, N 14.68; found C 33.52, H 4.76, N 14.60.

\subsubsection{Synthesis of ( $t$-Bu-DOTAH $)_{2}$-SBDC (6)}

To a $250 \mathrm{~mL}$ round-bottom flask fitted with a magnetic stir bar were added 4,4'-stilbene dicarboxylic acid (1, $1.34 \mathrm{~g}$, $5.0 \mathrm{mmol})$, freshly distilled sulfoxide chloride $(85 \mathrm{~mL})$ and $N, N$-dimethylformamide (DMF) $(0.5 \mathrm{~mL})$. The mixture was stirred at $75{ }^{\circ} \mathrm{C}$ for $4 \mathrm{~h}$. After completion of the reaction, the unreacted $\mathrm{SOCl}_{2}$ was recovered at $110{ }^{\circ} \mathrm{C}$, the residual $\mathrm{SOCl}_{2}$ was evaporated in vacuo and taken out by dichloromethane. The resulting residue was recrystallized with ethyl acetate, filtered, and washed with cold ethyl acetate. The product 4,4'-stibenedicarbonyl chloride (2) was got as green solid of $1.40 \mathrm{~g}$, yield $92 \%$. It was used without further purification. Then, to a suspension of compounds 2 ( $0.31 \mathrm{~g}$, 
$1 \mathrm{mmol})$ and $t$-Bu-DOTAH $(3,1.17 \mathrm{~g}, 2 \mathrm{mmol})$ in $\mathrm{CH}_{2} \mathrm{Cl}_{2}$ $(30 \mathrm{~mL})$ was added $\mathrm{K}_{2} \mathrm{CO}_{3}(0.27 \mathrm{~g}, 2 \mathrm{mmol})$ as acid-binding agent. The mixture was stirred at room temperature for $1 \mathrm{~h}$, then refluxed for $2 \mathrm{~h}$ (TLC, $10 \% \mathrm{CH}_{3} \mathrm{OH}-\mathrm{CH}_{2} \mathrm{Cl}_{2}$ ). After cooled, the solid was filtered, the filtrate was evaporated under reduced pressure and got beige solid. The crude product was purified over a silica flash column using 5\% $\mathrm{CH}_{3} \mathrm{OH}$ in $\mathrm{CH}_{2} \mathrm{Cl}_{2}$ as eluent, which resulted in the pure light yellow solid of 6 (1.26 g, yield, 90\%). m.p. 172.4 $174.5{ }^{\circ} \mathrm{C} ;{ }^{1} \mathrm{H}$ NMR $\left(300 \mathrm{MHz}, \mathrm{CDCl}_{3}\right) \delta: 7.88(\mathrm{~d}, J=7.9$ $\mathrm{Hz}, 4 \mathrm{H}), 7.43$ (d, J=7.8 Hz, 4H), 7.06 (s, 2H), 4.48 (s, 4H), $3.41(\mathrm{~s}, 4 \mathrm{H}), 3.16 \sim 2.02(\mathrm{~m}, 44 \mathrm{H}), 1.55 \sim 1.02(\mathrm{~m}, 54 \mathrm{H})$; ${ }^{13} \mathrm{C}$ NMR $\left(75 \mathrm{MHz}, \mathrm{CDCl}_{3}\right) \delta: 172.2,171.4,165.4,140.0$, 131.40, 129.4, 128.3, 126.4, 81.8, 81.6, 55.7, 55.6, 55.1, 28.0, 27.8; ESI-MS $m / z: 1427.7[\mathrm{M}+\mathrm{Na}]^{+}$. Anal. calcd for $\mathrm{C}_{72} \mathrm{H}_{116} \mathrm{~N}_{12} \mathrm{O}_{16}$ : C 61.52, H 8.32, N 11.96; found C 61.46, H 8.34, N 11.99 .

\subsubsection{Synthesis of (DOTAH) ${ }_{2}$-SBDC (7)}

A solution of $6(0.70 \mathrm{~g}, 0.5 \mathrm{mmol})$ in TFA $(10 \mathrm{~mL})$ was stirred at room temperature for $24 \mathrm{~h}$. TFA was removed under reduced pressure and the residue was dissolved in ethyl acetate $(5 \mathrm{~mL})$. Freezing for $12 \mathrm{~h}$, filtered to give compound 7 as a light yellow solid (quantitative). m.p. 159.6 162.4 ${ }^{\circ} \mathrm{C} ;{ }^{1} \mathrm{H}$ NMR $\left(300 \mathrm{MHz}, \mathrm{D}_{2} \mathrm{O}\right) \delta: 7.61(\mathrm{~d}, J=$ $5.8 \mathrm{~Hz}, 4 \mathrm{H}), 7.33$ (d, $J=6.4 \mathrm{~Hz}, 4 \mathrm{H}), 6.86(\mathrm{~s}, 2 \mathrm{H}), 4.00 \sim$ $2.93(\mathrm{~m}, 48 \mathrm{H}) ;{ }^{13} \mathrm{C}$ NMR $\left(75 \mathrm{MHz}, \mathrm{DMSO}-d_{6}\right) \delta$ : 171.0, $165.6,165.1,143.5,132.4,132.2,130.6,129.6,120.9$, $117.1,57.3,55.9,53.1,51.8$; ESI-MS m/z: $1145.4[\mathrm{M}+$ $2 \mathrm{~K}-\mathrm{H}]^{+}$. Anal. calcd for $\mathrm{C}_{48} \mathrm{H}_{68} \mathrm{~N}_{12} \mathrm{O}_{16}$ : C 53.92, H 6.41, N 15.72; found C 53.97, H 6.40, N 15.69.

\subsubsection{Synthesis of (Gd-DOTAH $)_{2}-\operatorname{SBDC}(\mathbf{8})$}

Method A: A solution of $7(0.27 \mathrm{~g}, 0.25 \mathrm{mmol})$ in water $(20 \mathrm{~mL})$ was mixed with a solution of $\mathrm{GdCl}_{3}$ in water $(0.05$ $\mathrm{mol} / \mathrm{L}, 10 \mathrm{~mL}, 0.5 \mathrm{mmol}$ ) while maintaining the $\mathrm{pH}$ at 6.5 by addition of $1 \mathrm{~mol} / \mathrm{L} \mathrm{NaOH}$. The solution was stirred at $50{ }^{\circ} \mathrm{C}$ for $24 \mathrm{~h}$. The $\mathrm{pH}$ was raised to 8.0. The solution was filtered through a $0.2 \mu \mathrm{m}$ filter, and the $\mathrm{pH}$ was lowered to 7.0 by adding $1 \mathrm{~mol} / \mathrm{L} \mathrm{HCl}$. The solution was loaded on a Hypersep C-18 cartridge, and the stationary phase was washed extensively with water. The product was recovered after gradient elution with $\mathrm{MeOH} / \mathrm{H}_{2} \mathrm{O}(V: V=1: 9$ to 3 : 2 ). The fractions containing the product were evaporated under reduced pressure to give $\mathbf{8}$ with a light yellow solid, $(0.29 \mathrm{~g}$, yield $85 \%)$.

Method B: To a suspension of compounds of $2(0.08 \mathrm{~g}$, $0.25 \mathrm{mmol})$ and Gd-DOTAH $(\mathbf{5}, 0.29 \mathrm{~g}, 0.5 \mathrm{mmol})$ in DMF $(10 \mathrm{~mL})$ was added $\mathrm{K}_{2} \mathrm{CO}_{3}(0.07 \mathrm{~g}, 0.5 \mathrm{mmol})$ as acid-binding agent. The mixture was stirred at room temperature for $4 \mathrm{~h}$. After completion of the reaction, the solid was filtered, the filtrate was evaporated under reduced pressure to obtain beige solid. The crude product was redissolved in water and loaded on a Hypersep C-18 cartridge, and the stationary phase was washed extensively with water. The product was recovered after gradient elution with $\mathrm{MeOH} /$ $\mathrm{H}_{2} \mathrm{O}$ from $1: 9$ to $3: 2$. The fractions containing the product were evaporated under reduced pressure to give $\mathbf{8}$ with a light yellow solid $(0.32$ g, yield $92 \%)$. m.p. $>300{ }^{\circ} \mathrm{C}$; ESI-MS $m / z: 1442.3\left[\mathrm{M}+\mathrm{CH}_{3} \mathrm{CN}+\mathrm{Na}\right]^{+}$. A correct $\mathrm{Gd}$ isotope pattern was observed. Anal. calcd for $\mathrm{C}_{48} \mathrm{H}_{62} \mathrm{Gd}_{2}-$ $\mathrm{N}_{12} \mathrm{O}_{16}$ : C 41.85, H 4.54, N 12.20; found C 41.80, H 4.55, N 12.23 .

\subsection{In vitro $\mathrm{MRI}$}

To obtain $T_{1}$ relaxation times of the aqueous solution of the new agents at different concentrations, following measurement parameters were used: repetition time $(\mathrm{TR})=$ $6000 \mathrm{~ms}$, number of data $=25$, and number of averages $(\mathrm{NA})=2$. While the $T_{2}$ relaxation times were determined with the following parameters: $\mathrm{TR}=6000 \mathrm{~ms}$, echo time $(\mathrm{TE})=1 \mathrm{~ms}$, echo count $=6000$ and $\mathrm{NA}=2$. Both $r_{1}$ and $r_{2}$ relaxivities were calculated by the linear fitting of $1 / T_{1}$ or $1 / T_{2}$ as a function of metal concentration. For $T_{1}$-weighted MR images, the instrument parameters were set as follows; $\mathrm{TR}=100 \mathrm{~ms}, \mathrm{TE}=18.2 \mathrm{~ms}$, imaging matrix $=192 \times 256$, slice thickness $=5 \mathrm{~mm}$, field of view $(\mathrm{FOW})=100 \mathrm{~mm} \times$ $100 \mathrm{~mm}$ and $\mathrm{NA}=2$.

Supporting Information ${ }^{1} \mathrm{H}$ NMR and ${ }^{13} \mathrm{C}$ NMR spectra, mass spectra of the synthesized compounds. The Supporting Information is available free of charge via the Internet at http://sioc-journal.cn/.

\section{References}

[1] Wei, R.; Gong, X.; Lin, H.; Zhang, K.; Li, A.; Liu, K.; Shan, H.; Chen, X.; Gao, J. Nano Lett. 2019, 19, 5394.

[2] Mi, P.; Kokuryo, D.; Cabral, H.; Wu, H.; Terada, Y.; Saga, T.; Aoki, I.; Nishiyama, N.; Kataoka, K. Nat. Nanotechnol. 2016, 11, 724.

[3] Wahsner, J.; Gale, E. M.; Rodríguez-Rodríguez, A.; Caravan, P. Chem. Rev. 2019, 119, 957.

[4] Idée, J.-M.; Port, M.; Robic, C.; Medina, C.; Sabatou, M.; Corot, C. J. Magn. Reson. Imaging. 2009, 30, 1249.

[5] Di Gregorio, E.; Gianolio, E.; Stefania, R.; Barutello, G.; Digilio, G.; Aime, S. Anal. Chem. 2013, 85, 5627.

[6] Marckmann, P.; Skov, L.; Rossen, K.; Dupont, A.; Damholt, M.-B.; Heaf, J.-G.; Thomsen, H.-S. J. Am. Soc. Nephrol. 2006, 17, 2359.

[7] Jost, G.; Lenhard, D.-C.; Sieber, M.-A.; Lohrke, J.; Frenzel, T.; Pietsch, H. Invest Radiol. 2016, 51, 83.

[8] Lauffer, R.-B. Chem. Rev. 1987, 87, 901.

[9] Caravan, P. Acc. Chem. Res. 2009, 42, 851.

[10] Hermann, P.; Kotek, J.; Kubicek, V.; Lukes, I. Dalton Trans. 2008, $23,3027$.

[11] Luo, J.; Li, W.-S.; Xu, P.; Zhang, L.-Y.; Chen, Z.-N. Inorg. Chem. 2012, 51, 9508.

[12] Zhao, G.; Lu, C.; Li, H.; Xiao, Y.; Zhang, W.; Fang, X.; Wang, P.; Fang, X.; Xu, J.; Yang, W. Inorg. Chim. Acta 2013, 406, 146.

[13] Zhao, G.; Li, H.; Lu, C.; Xiao, Y.; Fang, X.; Wang, P.; Fang, X.; Zhao, K.; Li, X.; Yin, S.; Xu, J.; Yang, W. RSC Adv. 2012, 2, 6404.

[14] Tiwari, A.-D.; Zhu, J.; You, J.; Eck, B.; Zhu, J.; Wang, X.; Wang, X.; Wang, B.; Silver, J.; Wilson, D.; Wu, C.; Wang, Y. J. Med. Chem. 2019, 62, 4902.

[15] Frullano, L.; Zhu, J.; Miller, R.-H.; Wang, Y. J. Med. Chem. 2013, $56,1629$.

[16] Frullano, L.; Zhu, J.; Wang, C.; Wu, C.; Miller, R.-H.; Wang, Y. J. Med. Chem. 2012, 55, 94.

[17] Sun, H.-S.; Li, Y.-L.; Jiang, H.; Guo, C.; Shen, L.-J. Chin. J. Org. Chem. 2018, 38, 1779 (in Chinese). (孙宏顺, 李玉龙, 蒋蕻, 郭成, 沈临江, 有机化学, 2018, 38, 1779.)

[18] Sun, H.-S.; Zhou, J.; Li, Y.-L.; Jiang, H.; Zhang, Y.; Wang, J.; Guo, 
C.; Shen, L.-J. Chin. J. Org. Chem. 2019, 39, 778 (in Chinese). (孙宏顺, 周进, 李玉龙, 蒋葓, 张艳, 王建强, 郭成, 沈临江, 有机化学, 2019, 39, 778.)

[19] Sun, H.-S.; Li, Y.-L.; Jiang, H.; Xu, N.; Lu, X.; Chen, Y. $C N$ 1077595333, 2017 [Chem. Abstr. 2018, 168, 326713].

[20] Wang, C.; Wu, C.; Popescu, D.-C.; Zhu, J.; Macklin, W.-B.; Miller, R.-H.; Wang, Y. J. Neurosci. 2011, 31, 2382.

[21] Wang, C.; Wu, C.; Zhu, J.; Miller, R.-H.; Wang, Y. J. Med. Chem. 2011, 54, 2331.

[22] Frullano, L.; Wang, C.; Miller, R.-H.; Wang, Y. J. Am. Chem. Soc. 2011, 133, 1611.

[23] Tiwari, A.-D.; Wu, C.; Zhu, J.; Zhang, S.; Zhu, J.; Wang, W.-R.; Zhang, J.; Tatsuoka, C.; Matthews, P.-M.; Miller, R.-H.; Wang, Y. J. Med. Chem. 2016, 59, 3705.

[24] Wu, C.; Eck, B.; Zhang, S.; Zhu, J.; Tiwari, A.-D.; Zhang, Y.; Zhu,
Y.; Zhang, J.; Wang, B.; Wang, X.; Wang, X.; You, J.; Wang, J.; Guan, Y.; Liu, X.; Yu, X.; Trapp, B.-D.; Miller, R.; Silver, J.; Wilson, D.; Wang, Y. J. Med. Chem. 2017, 60, 987.

[25] Zhou, J.; Yang, H.-D.; Sun, H.-S.; Li, Y.-L.; Jiang, H. Chin. J. Synth. Chem. 2017, 25, 159 (in Chinese).

(周进，杨海东，孙宏顺，李玉龙，蒋蕻，合成化学，2017，25, 159.)

[26] Aime, S.; Caravan, P. J. Magn. Reson. Imaging. 2009, 30, 1259.

[27] Frullano, L.; Tejerina, B.; Meade, T. J. Inorg. Chem. 2006, 45, 8489.

[28] Saini, N.; Varshney, R.; Tiwari, A. K.; Kaul, A.; Allard, M.; Ishar, M. P. S.; Mishra, A. K. Dalton Trans. 2013, 42, 4994.

[29] Gao. L.; Yu, J.; Liu, Y.; Zhou, J.; Sun. L.; Wang. J.; Zhu, J.; Peng, H.; Lu, W.; Yu, L.; Yan. Z.; Wang, Y. Theranostics 2018, 8, 92.

(Fan, Y.) 